\title{
A representação do espólio titular de ações nas assembléias das socie- dades anônimas
}

\author{
Ernesto Leme
}

\section{CONSULTA}

A. faleceu deixando grande quantidade de ações de duas sociedades anônimas. Os estatutos da primeira dessas sociedades rezam:

"A assembléia geral, órgão supremo da Comnanhia. é constituida por acionistas, inscritos, como tais, pelo menos com 30 dias de antecedência da convocação, reunidos em número legal, pessoalmente ou por seus procuradores ou representantes legais", (art. 14).

A segunda dessas sociedades anônimas, tem igual dispositivo no art. 18 de seus respetivos estatutos, com o acréscimo deste $\S$ único:

"As procurações e documentos comprobatórios da qualidade de acionista"

Em duas assembléias gerais realizadas depois do falecimento de A. ficou deliberado que os espólios desse acionista não podiam ter representante legal para o efeito de votar e 
ser votado, e consequentemente, de outros que implicassem ingerência na vida das mesmas sociedades anônimas.

Além dessas manif estações das assembléias gerais ocorre assinalar que esse órgão supremo das sociedades anônimas. orientam-se em sua deliberação, não só na letra de seus Estatutos a que incumbe regular

"os direitos e obrigações dos sócios entre si e entre eles e a sociedade", (art. 16 do dec. 434, de 1891),

como tambem em que:

a) a lei de sociedades anônimas só concede o exercício dos direitos inerentes às ações de tais sociedades aos proprietários das mesmas, a menos que os Estatutos queiram dispor o contrário (arts. 16, 21, 22, 23, 24, 32, 133, 135, 136 , etc.);

b) o Espólio não é pessoa jurídica, mas uma universalidade, (art. 57 do Código Civil);

c) a herança transmite-se, desde logo, aos herdeiros legítimos e testamentários, (art. 1.572 do Código Civil), e uma vez aberta em benefício de muitos herdeiros torna-se propriedade comum, e

d) "quando um desses títulos (ações) pertencer a diversas pessoas, a sociedade suspenderá o exercício dos direitos que a tais títulos são inerentes, enquanto um só individuo não for designado para junto dela figurar como proprietário", (art. 32 do dec. 434; de 1891).

Pelo exposto, pergunta-se: 
As sociedades anônimas acima referidas, negando ao inventariante de A., o direito de convocar assembléias gerais, e nelas votar e ser votado, e em resumo, de se envolver na sua administração com prejuizo do exercício dos atuais Diretores, legitimamente eleitos, procedem conforme o direito e a lei ?

\section{I}

Expedindo o juizo administrativo do inventário, um alvará autorizando o inventariante a proceder de maneira diversa ao deliberado pelas diretorias daquelas sociedades, estas são obrigadas a se submeter ao dito alvará, ou ao contrário, pódem recorrer ao Juizo comercial afim de fazer valer, de acôrdo com a letra da Lei de Sociedades Anônimas, os seus dispositivos estatutários?

No caso de resposta afirmativa á segunda pergunta:

\section{I I}

Qual o remédio judicial aconselhado para impedir a execução desse ato do juizo administrativo?

\section{PARECER}

1. O nosso Código Civil estabelece a representação das pessoas absoluta e relativamente incapazes, (art. 84), bem como das pessoas jurídicas, (art. 17). A herança é uma simples universitas juris, (art. 57). Será o inventariante representante legal do espólio, que administra?

2. Com a abertura da sucessão, "o domínio e a posse da herança transmitem-se, desde logo, aos herdeiros legíti- 
mos e testamentários", (art. 1.572). E, sendo os herdeiros maiores e capazes, poderão mesmo dispensar o inventário, fazendo partilha amigavel, na fórma prescrita em lei, (art. 1.773)

3. O inventariante é um méro "administrador legal", na frase de Coelho Da Rứcha, (Instituições de Direito Civil Português, 4." edição, II, 698), ou "administrador provisório da herança", no conceito de Dias Ferreira, (apud Astolpho de Rezende, Manual do Código Civil Brasileiro, XX, 176) Não tem a representação, ativa ou passiva, do espólio. Nem a que deriva de um oficio público, nem a que emana de uma pessoa juridica, nem a proveniente de um mandato, na classificação de $\mathrm{J}_{\mathrm{O}}$ SÉ Augusto CeSar, (Ensáio sobre os atos juridicos, p. 103). Daí o ensinamento de Gouvêa Pinto, (Tratado dos Testamentos e Successões, p. 443: “a representação dos herdeiros em juizo, não só em causas novas, como nas pendentes ao tempo da morte de seus antecessores, só a eles compete; e não, antes da partilha, a cabeças de casal, ainda que sejam cônjuges sobreviventes".

No caso de sociedade anônima, ocorrendo o falecimento de um acionista e passando as ações pertencentes ao de cujus, por efeito do art. 1.572 do Código Civil, ato contínuo, para o "domínio" e "posse" dos herdeiros legítimos, ou testamentários, a representação da hcrança caberá a esses herdeiros, em comum, e não ao inventariante, designando eles quem, dentre todos, deve legitimamente "figurar como proprietário", (decreto n. 434, de 4 de julho de 1891, art. 32).

4. Verdade seja que Soprano (L'assemblea generale degli azionisti, p. 96), por argumento dos arts. 903 e seguintes, do Código Civil Italiano, sustenta que, "se delle azioni facciano parte di un patrimonio ereditario, durante il tempo che questo si trova nel possesso degli esecutori testamentari questi delegheranno uno fra loro per intervento nell'assemblea e l'esercizio del diritto di voto". Mas, se isso é possivel no direito italiano, pelo qual se dá a transferência da posse 
dos bens do defunto aos herdeiros, "senza bisogno di materiale apprensione", (art. 925 do Codigo Civil), tal não se dá no direito brasileiro, onde os herdeiros são, desde a morte do antecessor, proprietários dos bens da herança, embora indivisa. $O$ inventariante, pois, nas assembléias das sociedades anônimas, apenas poderá agir, segundo as regras do art. 133, do decreto n. 434, de 1891, como mandatário dos herdeiros. E, tanto assim é, que os jurístas pátrios, ao enumerarem as pessoas que podem, com representação legal, tomar parte nas assembléias, exclúem sempre o inventariante, (conf. J. X. Carvalho de Mendonça, Tratado de Direito Comercial Brasileiro, IV, 17; SPENcER VAMPRÉ, Tratado Elementar de Direito Comercial, II, 207).

5. Em face do exposto, respondo aos itens da consulta pela maneira seguinte:

Ao $10^{\circ}-\mathrm{Sim}$.

Ao 2. - Fosse o inventariante do espólio de A. o "representante legal", a que se referem os estatutos das sociedades anônimas em questão, a simples prova de sua qualidade dar-lhe-ia direito a tomar parte nas assembléias gerais, ou de provocar a sua convocação, segundo a lei. Ao juiz do inventário falece competência para, mediante alvará, conferir ao inventariante poderes, que sómente aos herdeiros caberia outorgar.

Ao 3. - Recurso legal, no processo de inventário, sendo o caso; mandado de segurança; ação ordinária. no caso do art. 146, do decreto n. 434, de 4 de julho de 1891.

E' o que penso, salvo melhor juizo.

São Paulo, 2 de dezembro de 1937. 